\title{
Antibacterial, Antibiofilm and Antioxidant Activities of some Medicinal Plants from Pharmacopoeia of Tassili N’ajjer
}

\author{
Abdelkader Benhelima ${ }^{1,3 *}(\mathbb{D})$, Olivier Vidal ${ }^{2}(\mathbb{D})$ Zohra Kaid-Omar $^{3}(\mathbb{D})$, \\ Rabea Sahki ${ }^{4}$ (D) and Jean-Marie Lacroix ${ }^{2}$ (D) \\ ${ }^{1}$ Department of Process Engineering, Faculty of Technology, Dr. Tahar Moulay University, Saida 20000, Algeria. \\ ${ }^{2}$ Structural and Functional Glycobiology Unit (UGSF) CNRS UMR 8576, University of Sciences and Technologies \\ Lille, Cedex 59655, France. ${ }^{3}$ Department of Medicine, Faculty of Medicine, Djillali Liabes University, Sidi-Bel- \\ Abbes 22000, Algeria. ${ }^{4}$ National Forest Research Institute (INRF), Tamanrasset 11000, Algeria.
}

\begin{abstract}
Three plants adopted by nomads at Tassili n'ajjer (south Algeria) in traditional medicine namely, Cymbopogon schoenanthus, Anabasis articulata and Salvia chudaei, were analysed for theirs antibacterial, antibiofilm and antioxidant properties. Total flavonoid and phenolic contents were measured with $2 \% \mathrm{AlCl}_{3}$ and Folin-Ciocalteu's reagent method, respectively. The antibacterial propertie was investigated by measurement of MIC of plants extract inhibing bacterial proliferation. The antibiofilm propertie was calculated by fluorescent quantization of the DAPI labeled bacterial biomass fixed on the surface and by COMSTAT analysis of confocal scanning laser microscopy (CSLM) images. DPPH radical scavenging and $\beta$-carotene/linoleate bleaching methods were used to determine the antioxidant activities of the plants. Total phenolic content was ranged from 21.98 to 2.51 (gallic acid equivalents $\mathrm{mg} / \mathrm{g}$ methanolic extracts) and the total flavonoid content ranged from 19.27 to 1.65 (catechin equivalent $\mathrm{mg} / \mathrm{g}$ methanolic extracts). Antibacterial activity against four Gram positive bacteria was shown with plants extracts. The biofilm inhibition concentration of extracts decreasing $50 \%$ of biofilm cell density $\left(\mathrm{BIC}_{50}\right.$ ) for Salvia chudaei and Cymbopogon schoenanthus extracts ranges from 1 to $10 \mu \mathrm{g} / \mathrm{mL}$. CSLM images analysis revealed that both surface covering by germ and three dimensional development of the biofilm were reduced with plants extracts. For antioxidant activities, the methanol extracts of the plants evaluated showed low antioxidant activity, with a IC $\mathrm{C}_{50}$ between 1.94 and $6.16 \mathrm{mg} / \mathrm{ml}$. Thus, Our systematic research showed that this three common plants of Sahara desert has diversified phytochemicals possessing satisfying extent of antimicrobial, antibiofilm and antioxidant activities.
\end{abstract}

Keywords: Saharian plants, methanolic extracts, antibacterial, antibiofilm, antioxidant

*Correspondence: abdelkaderbenhelima@yahoo.fr; + 213771390057

(Received: April 08, 2020; accepted: August 05, 2020)

Citation: Benhelima A, Vidal O, Kaid-Omar Z, Sahki R, Lacroix J-M. Antibacterial, Antibiofilm and Antioxidant Activities of some Medicinal Plants from Pharmacopoeia of Tassili N’ajjer. J Pure Appl Microbiol. 2020;14(3):1835-1844. doi: 10.22207/JPAM.14.3.22

(C) The Author(s) 2020. Open Access. This article is distributed under the terms of the Creative Commons Attribution 4.0 International License which permits unrestricted use, sharing, distribution, and reproduction in any medium, provided you give appropriate credit to the original author(s) and the source, provide a link to the Creative Commons license, and indicate if changes were made. 


\section{INTRODUCTION}

Resistance to antibacterial molecules is a growing significant public health problem ${ }^{1}$. Even if a more accurate use of these molecules is required, discovery of new antibacterial compounds seems to be unavoidable. It is also true that, germs can generate biofilms whatever can form a sort of sticky gel, that forms its passage into various situations ranging from clinical to forming firms, and habitats where water and food are prepared and opportioned. On the other hand, these biofilms have learned activity to oppose antibiotics ${ }^{2}$.

Several ways of research must be taken to isolate active substances such as synthetic chemistry, or extraction of molecules isolated from microorganisms, fungi, algue, invertebrates or plants (peptides, phenolic compounds...). One of them is to identify the antimicrobial active substances of plants known for their use in traditional medicine ${ }^{3-5}$.

The flora of Algerian central Sahara (Tassili n'ajjer) presents a remarkably diversified vegetation of hundreds of endemic species that are valued by the local population in the field of traditional medicine ${ }^{6}$. In vitro and in vivo phytochemical researches have provided scientific justification and validation for their traditional uses $^{7}$. The therapeutic properties of these plants are related to the existence of secondary metabolites which are actually biologically active compounds. They are mainly phenolic compounds ${ }^{8}$ that exert their biological activities as antioxidant or antimicrobial ${ }^{9}$. Anabasis articulata (noted $\mathrm{Aa}$,
Chenopodiaceae), Cymbopogon schoenanthus (noted Cs, Poaceae) and Salvia chudaei (noted Sc, Lamiaceae) are three Saharian desert plants, used for theirs medicinal properties by the local population and known as "ajrem "," lemmad "and" tagrouft ", respectively ${ }^{10}$.

Analyzes carried out on $A$. articulata species revealed the presence of various compounds that can explain its medicinal potential, including phenol acids ${ }^{11}$. Several studies report the biological properties of essential oil of C. schoenanthus ${ }^{12}$. Aerial parts uses of $S$. Chudaei in local traditional medicine for the therapy of gonorrhea, spasms, abdominal pain and dysmenorrhea is well documented ${ }^{10}$.

In this work, phenolic compounds from these three plants were extracted using solubilization in methanol. The antibacterial, including antibiofilm development and antioxidant potentials of these extracts were determined thus validating their ancestral medicinal uses.

\section{MATERIALS AND METHODS \\ Plant materials}

Anabasis articulata (Forssk) Moq. (Chenopodiaceae), Cymbopogon schoenanthus (L.) Spreng. (Poaceae) and Salvia Chudaei Batt. \& Trab. (Lamiaceae) were collected from the Hoggar region (southern Algeria) during the flowering period, in 2019 (Table 1). Botanical identification was carried out by Dr. Rabea Sahki, in the National Forest Research Institute (INRF), Tamanrasset, Algeria. "A. articulata, C. schoenanthus and S. chudaei were deposited at Abdelhamid Ibn-Badis

Table 1. Locations, name and folkloric uses of plants subject of our study ${ }^{6}$.

\begin{tabular}{|c|c|c|c|c|c|c|}
\hline Scientific name & $\begin{array}{l}\text { Tamahaq } \\
\text { name }\end{array}$ & $\begin{array}{l}\text { Arabic } \\
\text { name }\end{array}$ & Part used & $\begin{array}{l}\text { Traditional } \\
\text { used }\end{array}$ & $\begin{array}{l}\text { Altitude } \\
\text { (m) }\end{array}$ & Latitude/ longitude \\
\hline $\begin{array}{l}\text { (Chenopodiaceae) } \\
\text { Anabasis } \\
\text { articulata }\end{array}$ & bender & ajrem & Air part & Skin diseases & 1459 & $\mathrm{~N} 22^{\circ} 48.205^{\prime} \mathrm{E}^{\circ} 5^{\circ} 36.949^{\prime}$ \\
\hline $\begin{array}{l}\text { (Poaceae) } \\
\text { Cymbopogon } \\
\text { schoenanthus }\end{array}$ & tiberimt & lemmad & $\begin{array}{l}\text { Whole } \\
\text { plant }\end{array}$ & $\begin{array}{l}\text { Respiratory } \\
\text { infections, } \\
\text { Urinary tract } \\
\text { infections }\end{array}$ & 1459 & $\mathrm{~N} 22^{\circ} 48.205^{\prime} \mathrm{E}^{\circ} 5^{\circ} 36.949^{\prime}$ \\
\hline $\begin{array}{l}\text { (Lamiaceae) } \\
\text { Salvia Chudaei }\end{array}$ & aouit & tagrouft & $\begin{array}{l}\text { Whole } \\
\text { plant }\end{array}$ & $\begin{array}{l}\text { Hepathic Liver } \\
\text { diseases, } \\
\text { palpitations, } \\
\text { anxiety }\end{array}$ & 1439 & $\mathrm{~N} 22^{\circ} 48.190^{\prime} \mathrm{E}^{\circ} 5^{\circ} 36.940^{\prime}$ \\
\hline
\end{tabular}


University and INRF herbarium with the voucher specimen number MPS2019/42, MPS2019/45 and MPS2019/43, respectively."

Prior to extraction, the plant material was dried and then ground.

Qualitative phytochemical analysis

The presence or absence of biologically active secondary metabolites was carried out on plants powder homogenate according to the standard methods described by Harbone ${ }^{13}$.

\section{Methanolic extraction}

Methanolic extraction was performed for 24 hours under stirring. The extract was purified and then was concentrated using a rotary evaporator until complete drying and stored at $+4^{\circ} \mathrm{C}$.

Quantitative phytochemical analysis Total phenols content (TPC) determination

The quantity of total phenols was measured with Folin-Ciocalteu reagent ${ }^{14}$ and gallic acid like a standard. Data were reported as milligram of gallic acid equivalent/gram methanolic extract (GAE mg/g).

\section{Determination of the total flavonoids content}

Colorimetric method with $\mathrm{AlCl}_{3}$ was adopted to quantify total flavonoids ${ }^{15}$ using catechin like a standard. Total flavonoid content was reported as milligram of catechin equivalent/ gram methanolic extract (CE mg/g).

\section{Determination of antimicrobial activity} evaluation

Minimal inhibitory concentration (MIC)

The antibacterial power of plant extracts against different bacteria was first estimated by the disk diffusion method as described by ${ }^{16}$ paralleling to the CLSI M02-A10 standard and clinical laboratory guidelines ${ }^{17}$. Strains of the succeeding bacterial species were used: Pseudomonas aeruginosa (kind gift from Reuben Ramphal) (Florida, USA), Escherichia coli, Proteus mirabilis,
Dickeya dadantii, Bacillus subtilis, Micrococcus luteus (kinds gift from Michel Simonet from National Institute of Health and Medical Research (INSERM) U801 France), Staphylococcus aureus (ATCC ${ }^{\circledR} 25923^{\mathrm{TM}}$ ) was obtained from American Type Culture Collection (ATCC), and Streptococcus gordonii DSM20568, species were obtained from Structural and Functional Glycobiology Unit (UGSF) laboratory collection, Lille, France.

The MIC of plant extracts with antibacterial activity was examined by microdilution technique ${ }^{18,19}$ in 96 -well microplates. Wells were filled with $0.1 \mathrm{ml}$ of bacteria corresponding to 5. $10^{7} \mathrm{CFU} / \mathrm{mL}$ obtained from an overnight culture grown at $37^{\circ} \mathrm{C}$ in MHB (Muller Hinton broth). Test wells were finally filled-up with $20 \mu \mathrm{L}$ of dilutions of extracts while control wells were filled-up with or without $20 \mu \mathrm{L}$ of methanol used as solvent for the plant extract dilutions. Each analysis was replicated three times ${ }^{20}$.

Microbial growth was measured with a microplate reader (Clariostar fluorescence plate reader, BMG-Labtek) at $600 \mathrm{~nm}$.

\section{Biofilm inhibition evaluation}

S. aureus (ATCC ${ }^{\circledR} 25923^{\text {TM }}$ ) or M. Luteus (kind gift from Michel Simonet from National Institute of Health and Medical Research (INSERM) U801 France) were grown at $37^{\circ} \mathrm{C} / 16 \mathrm{~h}$ in $\mathrm{LB}$ (lysogeny broth) medium and diluted to $10^{6} \mathrm{CFU} /$ $\mathrm{mL}$ in the same medium added with $10 \mu \mathrm{g} / \mathrm{mL}$ of $4^{\prime}, 6^{\prime}$-diamidino-2-phenylindole (DAPI, Sigma). 12-wells cell culture plates (Greiner Bio-One, Black, FB) were inoculated with $1 \mathrm{~mL}$ of this bacterial suspension then filled-up with $100 \mu \mathrm{L}$ of dilutions of extracts ranging from 0,1 to 100 $\mu \mathrm{g} / \mathrm{ml}$ while control wells were filled-up with or without $100 \mu \mathrm{L}$ of methanol used as solvent for the plant extract dilutions. Biofilms were incubated at $37^{\circ} \mathrm{C}$ in $\mathrm{CO}_{2}$ incubator Herace ${ }^{\mathrm{TM}} 150 \mathrm{i}$ (Thermo Scientific) during $24 \mathrm{~h}^{21}$. DAPI display no

Table 2. Phytochemical screening of different plant powder homogenate

\begin{tabular}{lcccccc}
\hline Plant name & Alcaloids & Saponins & Tanins & Flavonoids & Steroids & Terpenoids \\
\hline A. articulata & + & + & + & + & + & - \\
C. schoenanthus & - & + & + & + & - & + \\
S. Chudaei & - & + & + & + & - & + \\
\hline
\end{tabular}

"+" means presence, while "-" means absence of each compound in the plant 
fluorescence in solution and no effect towards germ cell. Biofilms were washed four times with Dulbecco's phosphate buffered saline (DPBS) to quantify fluorescence. Surface colonization in each well was evaluated by quantification of DAPI associated fluorescence (excitation $350 \mathrm{~nm} /$ emission $460 \mathrm{~nm}$ ) with Clariostar fluorescence plate reader (BMG-Labtek).

\section{Biofilms Three-dimensional organization}

Biofilm three-dimensional organization was examined by confocal laser scanning microscopy (CLSM) and imaged with ZEN 2009 Light Edition program. Biofilm were developed as described just before except that incubation was performed in Permanox Chamber Slide (Nunc ${ }^{\circledR}$ Lab-Tek $^{\circledR}$ Chamber Slide $^{\text {TM }}$ system) and after washing, biofilms were fixed (PFA 4\%) and mounted with Mowio| ${ }^{\circledR}$ 4-88.

Zeiss confocal microscope (LSM780) with 40x objective 1.3NA Oil Plan-Apochromat DIC was used to observe biofilms. The DAPI die was stimulated using a $405 \mathrm{~nm}$ laser diode and the emission was accumulated between $410-500 \mathrm{~nm}$ on GaAsP detector.

Table 3. Total phenolic and flavonoid content of plant extracts

\begin{tabular}{lcc}
\hline Plant/standard & $\begin{array}{c}\text { TPC } \\
\text { (GAE mg/g) }\end{array}$ & $\begin{array}{c}\text { TFC } \\
\text { (CE mg/g) }\end{array}$ \\
\hline A. articulata & $02,51 \pm 0,06$ & $01,65 \pm 0,04$ \\
C. schoenanthus & $03,59 \pm 0,10$ & $02,96 \pm 0,07$ \\
S. Chudaei & $21,98 \pm 0,82$ & $19,27 \pm 0,61$ \\
\hline
\end{tabular}

TPC: Total phenolic content (mg GAE/g methanolic extract); TFC: Total flavonoid content ( $\mathrm{mg} \mathrm{CE} / \mathrm{g}$ methanolic extract)
Architectural analysis was performed using the COMSTAT program ${ }^{22}$. The image stacks captured for each CSLM analysis were analysed for the four succeeding architectural characteristics: size of the biofilm dissociated by substratum area $\left(\mu \mathrm{m}^{3} / \mu \mathrm{m}^{2}\right)$ indicating total biomass of germ, biofilm average thickness $(\mu \mathrm{m})$ as well as maximum thickness $(\mu \mathrm{m})$, roughness coefficient (adimensional) measuring biofilm surface diversity reflecting variations of biofilm thickness, substratum coverage (\%) indicating the capability with which germ developed on the surface.

\section{Antioxidant activity}

The antioxidant activity of the methanolic extracts was measured paralleling to two methods. DPPH scavenging radical activity

The capacity to catch 1,1-diphenyl-2picrylhydrazyl radicals (DPPH) by methanolic extracts was determined by the method of KhaledKhodja $^{23}$.

The $\mathrm{IC}_{50}$ concentration which inhibits $50 \%$ of the DPPH groups present in the mixture was calculated using the graph I $(\%)=f(C)$ where (C) is the concentration of standard/methanolic extract. These same data were also reported in AEAC (Ascorbic acid Equivalent Antioxidant Capacity) according to the method of Bassolé24. Butylated hydroxyanisole and ascorbic acid (BHA) were employed as witness.

\section{$\beta$-carotene/linoleate model system}

The rate of antioxidant activity (AA \%) was measured according to the method described by Abdolhamid ${ }^{25}$.

\section{Statistical analysis}

All results are expressed as the average \pm SD of three tests. The statistical analysis of the

Table 4. Antibacterial activity of methanolic plant extracts against four Gram positive bacteria

\begin{tabular}{|c|c|c|c|c|c|c|}
\hline \multirow[t]{3}{*}{ Plant } & \multicolumn{6}{|c|}{ Bacterial species } \\
\hline & \multirow{2}{*}{$\begin{array}{l}\text { B. subtilis } \\
\text { MIC } \\
\text { (mg/ml) }\end{array}$} & \multirow{2}{*}{$\begin{array}{l}\text { S. gordonii } \\
\text { MIC } \\
(\mathrm{mg} / \mathrm{ml})\end{array}$} & \multicolumn{2}{|c|}{ S. aureus } & \multicolumn{2}{|c|}{ M. luteus } \\
\hline & & & $\begin{array}{c}\overline{\mathrm{MIC}} \\
(\mathrm{mg} / \mathrm{ml})\end{array}$ & $\begin{array}{c}\text { BIC50 } \\
(\mu \mathrm{g} / \mathrm{ml})\end{array}$ & $\begin{array}{c}\mathrm{MIC} \\
(\mathrm{mg} / \mathrm{ml})\end{array}$ & $\begin{array}{c}\mathrm{BIC50} \\
(\mu \mathrm{g} / \mathrm{ml})\end{array}$ \\
\hline A. articulata & 2 & 1 & 2 & $>100$ & 0.1 & $>10$ \\
\hline C. schoenanthus & 2 & 2 & 0.2 & 10 & 0.5 & 1 \\
\hline S. chudaei & 0.5 & 0.2 & 0.5 & 10 & 0.5 & 1 \\
\hline
\end{tabular}

MIC: Minimal Inhibitory Concentration; BIC50: Biofilm Inhibition Concentration of extracts able to reduce more than $50 \%$ of biofilm cell density 
data was carried out by the one-way ANOVA. To complete the statistical analysis multi-comparison Dunnett's test was performed.

\section{RESULTS}

The methanolic extracts yields of $A$. articulata, C. schoenanthus and S. chudaei, expressed in relation to dry weight plant were 6.2 $\%, 7.3 \%$ and, $22.6 \%$, respectively.

Qualitative phytochemical analysis

Phytochemical tests of Anabasis articulata (Aa) Cymbopogon schoenanthus (CS) and Salvia Chudaei $(\mathrm{Sc}$ ) extracts showed the existence of saponins, flavonoids and tannins (Table 2).

\section{Quantitative phytochemical analysis}

Total phenol content (TPC) of all extract was measured. Values were expressed as $\mathrm{mg}$ gallic acid equivalent/g methanolic extract (GAE mg/g) (Table 3). Sc extract has a seven-fold higher TPC value $(21.98 \pm 0.82 \mathrm{GAE} \mathrm{mg} / \mathrm{g})$ as compared to Cs extract ( $3.59 \pm 0.10 \mathrm{GAE} \mathrm{mg} / \mathrm{g}$ ) and eight-fold higher as compared to $A a$ extract containing (2.51 $\pm 0.06 \mathrm{GAE} \mathrm{mg} / \mathrm{g}$ ).

Total flavonoid content (TFC) of all extract was also measured. Results were represented as $\mathrm{mg}$ catechin equivalent/g methanolic extract (CE $\mathrm{mg} / \mathrm{g}$ ) (Table 3). The same kind of results were observed since Sc extract contains a six-fold higher amount of flavonoid, with (19.27 $\pm 0.61 \mathrm{CE} \mathrm{mg/g}$ ) as compared to Cs extract ( $2.96 \pm 0.07 \mathrm{CE} \mathrm{mg} / \mathrm{g}$ ) and more than a eleven-fold higher amount as compared to $A a$ extract (1.65 $\pm 0.04 \mathrm{EC} \mathrm{mg} / \mathrm{g}$ ).
These data suggest that $S c$ display the best activity potential.

\section{Antibacterial activity}

Antibacterial activity is also often associated with molecules extracted from plants. Antibacterial activities of $S c, C s$ and $A a$ extracts on four Gram-positive bacteria species and four Gram-negative bacteria species was first tested by the disk diffusion method. The four Gram-positive bacteria species examined were sensitive to all extracts. Unfortunately, no antibacterial activity was observed against Gram-negative bacteria (data not shown). Antibacterial inhibition of growth was then analyzed in liquid condition for the Grampositive bacteria species in medium containing various plant extract concentration allowing calculation of minimal inhibition concentration (MIC). All the plant extracts displayed inhibition of bacterial growth with a MIC classifying from 0.1 to $2.0 \mathrm{mg} / \mathrm{mL}$ (Table 4). Thus each methanolic extract contained active antibacterial compounds of the plants. Sc extract displayed the best MIC with 0.2 to $0.5 \mathrm{mg} / \mathrm{mL}$ against the four bacterial species, while Aa presented the lower $(2 \mathrm{mg} / \mathrm{mL}$ for three of the four tested germs). MIC of each plant extract reflects directly the total concentration of phenolic compounds and particularly flavonoids (Table 3), as expected for plant biological compound containing such families of molecules.

\section{Antibiofilm activity}

Antibiofilm activity of each extract was tested against two Gram positive bacteria,

Table 5. COMSTAT analysis of CSLM images of biofilm of M. luteus and S. aureus in presence of $10 \mu \mathrm{g} / \mathrm{mL}$ of Sc or of Cs extracts

\begin{tabular}{|c|c|c|c|c|c|}
\hline & $\begin{array}{c}\text { Total } \\
\text { biomass } \\
\left(\mu \mathrm{m}^{3} / \mu \mathrm{m}^{2}\right)\end{array}$ & $\begin{array}{l}\text { Roughness } \\
\text { coefficient }\end{array}$ & $\begin{array}{l}\text { Maximum } \\
\text { thikness } \\
(\mu \mathrm{m})\end{array}$ & $\begin{array}{c}\text { Average } \\
\text { thikness } \\
(\mu \mathrm{m})\end{array}$ & $\begin{array}{c}\text { Surface } \\
\text { coverage } \\
(\%)\end{array}$ \\
\hline M. luteus & $4.21 \pm 0.89$ & $1.05 \pm 0.39$ & $35.15 \pm 5.26$ & $10.57 \pm 2.52$ & $19.33 \pm 5.76$ \\
\hline $\begin{array}{l}\text { Sc } 10 \\
(\mu \mathrm{g} / \mathrm{mL})\end{array}$ & $0.06 \pm 0.05$ & $1.93 \pm 0.07$ & $5.21 \pm 0.43$ & $0.06 \pm 0.06$ & $2.90 \pm 2.83$ \\
\hline $\begin{array}{l}\text { Cs } 10 \\
(\mu \mathrm{g} / \mathrm{mL})\end{array}$ & $0.07 \pm 0.12$ & $1.92 \pm 0.14$ & $5.79 \pm 3.08$ & $0.06 \pm 0.10$ & $0.10 \pm 0.09$ \\
\hline S. aureus & $2.81 \pm 0.68$ & $0.59 \pm 0.04$ & $14.90 \pm 3.05$ & $4.24 \pm 1.11$ & $59,01 \pm 7.82$ \\
\hline $\begin{array}{l}\text { Sc } 10 \\
(\mu \mathrm{g} / \mathrm{mL})\end{array}$ & $0.52 \pm 0.46$ & $1.65 \pm 0.25$ & $9.84 \pm 1.75$ & $0.59 \pm 0.48$ & $13.69 \pm 11.06$ \\
\hline $\begin{array}{l}\text { Cs } 10 \\
(\mu \mathrm{g} / \mathrm{mL})\end{array}$ & $0.19 \pm 0.03$ & $1.85 \pm 0.04$ & $11.54 \pm 1.57$ & $0.25 \pm 0.04$ & $5,91 \pm 1.68$ \\
\hline
\end{tabular}

Sc: Salvia chudaei extract, Cs: Cymbopogon schoenanthus extract. Values represent means \pm SD. 
M. luteus and the pathogen S. aureus. Biofilm formation occurred on abiotic surface during $24 \mathrm{~h}$ in LB medium with or without various concentration of plant extract. Biofilm development was assessed by fluorescent quantization of the DAPI defined bacterial biomass deposed on the surface (Table 4) and by COMSTAT analysis of confocal scanning laser microscopy (CSLM) images (Table 5). Plant extract concentrations inhibiting bacterial growth (i.e. around the MIC) will also prevent biofilm formation. Thus only subinhibitory concentrations (below $10 \mu \mathrm{g} / \mathrm{mL}$ for M. luteus and below $100 \mu \mathrm{g}$ / $\mathrm{mL}$ for $S$. aureus) allowing bacterial growth were tested. The biofilm elimination concentration of extracts decreasing $50 \%$ of biofilm cell density $\left(\mathrm{BIC}_{50}\right)$ was measured (Table 4). Cs and Sc extracts displayed antibiofilm activity at concentration as low as $1 \mu \mathrm{g} / \mathrm{mL}$ for $M$. luteus and $10 \mu \mathrm{g} / \mathrm{mL}$ for $S$. aureus, while extracts of $A a$ display no antibiofilm activity at all the concentrations tested for $S$. aureus and for M. luteus (Table 4).

Reduction of biofilm formation can result from lower bacterial density but may also reflect disorganization of the overall structure. Thus, we decided to analyze the three-dimensional configuration of the biofilm elaborated with $M$. luteus and $S$. aureus in the existence of 10 $\mu \mathrm{g} / \mathrm{mL}$ of $\mathrm{CS}$ and Sc extracts. COMSTAT analysis confirmed the efficiency of both plant extracts to inhibit biofilm formation. Image analyses showed that $M$. luteus biofilm and $S$. aureus biofilm grown in presence of $10 \mu \mathrm{g} / \mathrm{mL}$ of each plant extract contained less biomass (Table 5), with a large decrease (between 81.5 and $98.6 \%$ ) of the biomass as compared to the controls. In addition, biofilms developed in presence of plant extracts displayed a higher roughness coefficient (mostly twice higher, Table 5) than control indicating that biofilm structure was less homogeneous. The biofilm average and maximum thickness were also strongly reduced for both $M$. luteus and $S$. aureus when grown in presence of plant extracts as compared to the control (Table 5). Plant extracts led finally to the development of a thin and sparse biofilm containing only $1.4 \%$ to $18.5 \%$ of the biomass of the untreated samples. Finally, biofilms grown in the presence of both plant extracts displayed a lower surface coverage than the

Table 6. Scavenging power of plant extracts

\begin{tabular}{lccc}
\hline Plant/standard & $\begin{array}{c}\text { DPPH } \\
\text { IC }\end{array}$ & $\begin{array}{c}\text { AEAC } \\
(\mathrm{mg} / \mathrm{ml})\end{array}$ & $\begin{array}{c}\beta \text {-carotene } \\
\text { (AA\%) }\end{array}$ \\
\hline A. articulata & 6.16 & 2435.06 & $8.47 \pm 0.77$ \\
C. schoenanthus & 4.36 & 3440.37 & $10.13 \pm 1.15$ \\
S. Chudaei & 1.94 & 7731.96 & $15.61 \pm 1.29$ \\
Ascorbic Acid & 0.15 & ND & $40.98 \pm 2.51$ \\
Gallic Acid & NA & NA & $47.07 \pm 2.73$ \\
BHA & 0.16 & 93750 & $37.69 \pm 2.62$
\end{tabular}

IC50: Inhibition Concentration 50\%; AEAC: Ascorbic acid Equivalent Antioxidant Capacity (mg AA/100 g); NA: Not Applicable; ND: Not Done; Values are average of three independent replicates \pm SD.

Table 7. Correlation matrix between phenolic compounds and antioxidant activities of methanolic plant extracts

\begin{tabular}{lcccc}
\hline \multirow{2}{*}{ Tests } & \multicolumn{4}{c}{ Correlation coefficient $(r)$} \\
\cline { 2 - 5 } & TPC & TFC & $I_{50}$ & AA \\
\hline $\mathrm{IC}_{50}$ & 0.91 & 0.95 & 1 & 0.94 \\
$\mathrm{AA}$ & 0.97 & 0.98 & 0.93 & 1 \\
\hline
\end{tabular}

TPC: Total phenolic content (mg GAE/g), TF: Total flavonoid content (mg CE/g); IC50: Inhibition Concentration 50\%; AA: Antioxidant Activity. control (Table 5) and showed an increased number of holes in overall structure. Consequently, while growth of $S$. aureus and $M$. luteus in presence of subinhibitory concentrations of $S c$ and CS plant extracts is unaffected, their ability to build a biofilm is severely reduced. Taken together, these data demonstrate that both plant extracts can reduce the surface colonization by bacteria and prevent biofilm development.

\section{Antioxidant activity}

The scavenging power of the three methanolic extracts was examined with two free 
radical scavenging tests. $A a, C s$ and $S c$ methanolic extracts activities were first evaluated against scavenging DPPH radical (Table 6). The results showed that each extract has a free radical scavenging power. As expected, Sc extract was the best free radical inhibitor with a calculated IC $C_{50}$ of $1.94 \mathrm{mg} / \mathrm{mL}$ succeeded by $C s$ extract with an IC of $4.36 \mathrm{mg} / \mathrm{mL}$ and finally $A a$ extract with an $\mathrm{IC}_{50}$ of $6.16 \mathrm{mg} / \mathrm{mL}$ compared with ascorbic acid and BHA having $\mathrm{IC}_{50}$ of 0.15 and $0.16 \mathrm{mg} / \mathrm{mL}$, respectively. The methanolic extracts showed little antioxidant activity with $\mathrm{IC}_{50}$ values between 10 and 60 times higher than some flavonoids, renowned DPPH free radical scavengers.

For each extract, DPPH radical scavenging power was directly correlated with total phenolic and flavonoid content measured $\left(R^{2}=0.91\right)$ and $\left(R^{2}=0.95\right)$, respectively (Table 7$)$.

To confirm these results, a second free radical scavenging test was used with $\beta$-carotene / linoleate model system (Table 6). After 2 hours, the elimination percentage of bleaching $\beta$-carotene of $C S, S c$ and $A a$ extracts were between $08.47 \pm$ $0.77 \%, 10.13 \pm 1.15 \%$ and $15.61 \pm 1.29 \%$ against $47.07 \pm 2.73 \%, 40.98 \pm 2.51 \%$ and $37.69 \pm 2.62 \%$, for standards gallic acid, ascorbic acid and BHA, respectively. The whitening inhibition hierarchy of the extracts (i. e. $S c$ extract $>C s$ extract $>A a$ extract) was correlated with total phenolic and flavonoid concentration contained in each extract $\left(R^{2}=0.97\right)$ and $\left(R^{2}=0.98\right)$, respectively (Table 7$)$.

\section{DISCUSSION}

Most plants contain numerous phytochemicals compounds having biological activity with medicinal properties, like antibacterial and/or antioxidant activities. For some of them, our ability to extract these phytochemicals within essential oils allowed their use in alternative medicine and subsequently their detailed characterization ${ }^{26}$. In this work, we demonstrated the antibacterial, antibiofilm and antioxidant properties of some local medicinal plants from the central desert (Tassili n'ajjer) that are frequently used in local traditional medicine, thus demonstrating their potential for use in human therapy on a larger scale.

Phytochemical analysis

Previous study on Cs has endeavored to validate its traditional use. It has been reported the isolation of limonene, $\beta$-phellandrene, $\delta$-terpinene and $\alpha$-terpineol in essential oil extract. These compounds were found to possess in vitro, significant antiacetylcholinesterase, antimicrobial and antioxidant properties ${ }^{11,27}$. Phytochemical investigations of $A a$ have shown the existence of several constituents, like phenolic compounds ${ }^{8}$. Several studies have highlighted the biological properties of phytochemicals constituents extracted from various plants like antibacterial, antifungal and antioxidant activity ${ }^{28}$. The amount of extractible secondary metabolites, such as TPC, often present a great variability in the literature, depending on the environmental conditions of plant growth (salinity, temperature...), biological factors (mainly plant organ and genotype) as well as extraction method (namely the type of solvent used $)^{29}$.

\section{Antibacterial activity}

Many plant extracts are known for their antibacterial properties, particularly effective against pathogenic species ${ }^{30}$. This overall antibacterial activity is usually correlated with the synthesis of secondary metabolites, especially phenolic compounds, exhibiting this antibacterial effect ${ }^{30}$. All Methanolic extracts of $A a, C S$ and Sc display antibacterial effect on four Gram-positive germs species while no effect was detected on Gram negative species As observed for the antioxidative activity, the antibacterial activity is also the best for Sc extract, but the two other extracts, differing largely in TPC, are quite equivalent for antibacterial activity even if $C s$ is particularly effective against $S$. aureus while $A a$ is the more efficient against M. luteus. For the two other plant extracts, explanation of one specific antibacterial activity has to be dig deeper by complete characterization by Gas Chromatography-Mass Spectrometry Analysis.

It is difficult to explain why all plant extracts show no antibacterial effect on Gram negative germs. Despite the large difference in envelope composition between Gram negative and Gram positive germs, it is now appropriately known that antibacterial effect of phenolic compounds is mostly due to membrane disruption with, to a less extend, intracellular enzymes activity inhibition (topoisomerases, kinases...) ) $^{30}$. Before the present article no other work described antibacterial activity for plants extracts of $A a$ and 
Sc and the only antibacterial activity reported in the literature concerns $C$ s acetone/water extracts demonstrating Streptococci inhibition of growth at concentration ranging from 4 to $8 \mathrm{mg} / \mathrm{mL}^{8}$ which is in agreement with the $C s$ antibacterial activity (1 $\mathrm{mg} / \mathrm{mL}$ ) reported here against $S$. gordonii. Indeed, the medicinal potential of each plant extract is the consequence of the extraction of the phenolic compounds by simple methanolic extraction.

\section{Antibiofilm activity.}

Skin infection caused by bacteria such as $S$. aureus, results mostly from penetration of wounded tissue by bacteria already present at skin surface. The persistence of these bacteria is the result of its ability to colonize skin surface ${ }^{31}$ and develop biofilm structure on any kind of biotic or abiotic surface (catheter, implants, prothesis, etc... $)^{32}$. When established in a biofilm structure, bacteria are more protected against host defenses, antibiotics and most of the known antibacterial compounds used in medicine. It is of great importance in therapeutic strategies to prevent biofilm formation, particularly the initial colonization events.

In the literature, antibiofilm activity of plant extracts is mostly measured using concentration above or equal to the MIC mostly because it is believed that biofilm development allows stronger protection against antibacterial compounds. In the present work, subinhibitory concentrations of each plant extracts were used to prevent biofilm development of two bacterial species usually associated with human skin, the non-pathogen $M$. luteus and the pathogen $S$. aureus. Interestingly, the biofilm inhibition concentration of $C s$ and Sc plant extracts able to reduce more than $50 \%$ of the biofilm cell density $\left(\mathrm{BIC}_{50}\right.$ ) display values as low as $2 \%$ to $10 \%$ of the MIC calculated, while no inhibition of biofilm development was observed for Aa plant extract at the concentration used. At subinhibitory concentrations, while they are unable to prevent bacterial growth in culture medium, methanolic plant extracts exert a strong inhibitory effect on the bacterial ability to form biofilms.

COMSTAT analyses of CSLM images of biofilms with plant extracts show that the biofilm architecture is strongly reduced. This reduction of biofilm structure is probably the result, in a large part, of reduction of the surface colonization determinant step required for normal biofilm formation. It is largely described in the literature that surface colonization by bacteria depends on the presence of a conditioning film of organic compounds coming from the medium and covering the immersed surface attracting bacteria and making this local environment suitable to biofilm development. One can imagine in our experiments that phenolic compounds of the plant extract displaying antibacterial activity may have adsorb on the surface generating a nonsuitable surface to colonize for the bacteria. Plant extracts leads finally to the development of a thin and sparse biofilm containing only $1.4 \%$ to $18.5 \%$ of the biomass of the untreated samples. Since methanol can quickly evaporate at temperature above $30^{\circ} \mathrm{C}$, methanolic extract containing phenolic compounds might be of interest for surface treatment against bacterial colonization. Antioxidant activity

Over phenolic compounds, flavonoids have the best antioxidant and are the most useful in human health ${ }^{11}$. Recently, research of new sources of natural antioxidants has attracted increasing attention of the scientific community to these compounds since they are inexpensive and safe $^{33}$. Our systematic research exposed that the medicinal plants selected $A a, C S$ and $S c$ are rich in polyphenols. A positive relationship was found between the TPC and diverse scavenging actions evaluated in vitro, signifying that polyphenols could be the principal contributors to the elimination of free radicals and to the capacity to reduce extracts ${ }^{23}$. The three plant extracts tested displayed an important antioxidant activity as demonstrated by free radical scavenging and inhibition of lipid peroxidation experiments. These results are directly correlated with the TPC and TFC quantization of each plant extract ascertaining a direct rapport between Scavenging power and concentration of polyphenols inside of plants used in traditional medicine. These results indicated that each methanolic extract obtained from the three plants during this work has an antioxidant activity in proportions corresponding to what has been reported in the literature for $A a^{11}$ and $C s^{12,34}$ respectively.

\section{CONCLUSION}

The high antibacterial and antibiofilm 
activity associated with the high antioxidant activity of the plant extracts justifies their use for medicinal purposes and suggests that they can be used as a potential source of metabolites, nutritional supplement and alternative preservatives of food or in the pharmaceutical industry.

\section{ACKNOWLEDGMENTS}

None.

\section{CONFLICT OF INTEREST}

The authors declare that there is no conflict of interest.

\section{AUTHORS' CONTRIBUTION}

All the authors have made direct contribution on idea creation, research work and editing of the manuscript.

\section{FUNDING}

None.

\section{ETHICS STATEMENT}

This article does not contain any studies with human participants or animals performed by any of the authors.

\section{DATA AVAILABILITY}

All datasets generated or analyzed during this study are included in the manuscript and are available with the corresponding author.

\section{REFERENCES}

1. Tang KL, Caffrey NP, Nobrega DB, et al. Restricting the use of antibiotics in food-producing animals and its associations with antibiotic resistance in food-producing animals and human beings: a systematic review and meta-analysis. Lancet Planet Health. 2017;1:E316-E327. doi: 10.1016/S25425196(17)30141-9

2. Rounds $L$, Havens CM, Feinstein $Y$, Friedman $M$, Ravishankar S. Plant Extracts, Spices, and Essential Oils Inactivate Escherichia coli 0157:H7 and Reduce Formation of Potentially Carcinogenic Heterocyclic Amines in Cooked Beef Patties. J AGR Food Chem. 2012;60:3792-3799. doi: 10.1021/jf204062p

3. Tajkarimi MM, Ibrahim SA, Cliver DO. Antimicrobial herb and spice compounds in food. Food Control. 2010;21(9):1199-1218. doi: 10.1016/j. foodcont.2010.02.003

4. Brown DG, Lister T, May-Dracka TL. New natural products as new leads for antibacterial drug discovery. Bioorg. Med Chem Lett. 2014;24(2):413-418. doi: 10.1016/j.bmcl.2013.12.059
5. Gyawali R, Ibrahim SA. Natural products as antimicrobial agents. Food Control.2014;46:412-429. doi: 10.1016/j. foodcont.2014.05.047

6. Sahki A, Sahki R. Le Hoggar promenade botanique. Edition Esope Chamonix, France. 2004

7. Nadpal JD, Lesjak MM, Mrkonjic ZO, et al. Phytochemical composition and in vitro functional properties of three wild rose hips and their traditional preserves. Food Chem. 2008;241:290-300. doi: 10.1016/j. foodchem.2017.08.111

8. Lou S-N, Ho C-T. Phenolic compounds and biological activities of small-size Citrus: Kumquat and calamondin. J Food Drug Anal. 2017;25(1):162-175. doi: 10.1016/j. jfda.2016.10.024

9. Pereira MC, Oliveira DA, Hill LE, et al. Effect of nanoencapsulation using PLGA on antioxidant and antimicrobial activities of guabiroba fruit phenolic extract. Food Chem. 2018;240:396-404. doi: 10.1016/j.foodchem.2017.07.144

10. Hammiche V, Maiza K. Traditional medicine in Central Sahara: Pharmacopoeia of Tassili N'ajjer. J Ethnopharmacol. 2006;105(10):358-367. doi: 10.1016/j.jep.2005.11.028

11. Djeridane A, Hamdi A, Bensania W, Cheifa K, Lakhdari I, Yousfi M. The in vitro evaluation of antioxidative activity, $\alpha$-glucosidase and $\alpha$-amylase enzyme inhibitory of natural phenolic extracts. Diabetes Metab Syndr. 2015;9(4):324-331. doi: 10.1016/j. dsx.2013.10.007

12. Khadri A, Neffati M, Smiti S, et al. Antioxidant, antiacetylcholinesterase and antimicrobial activities of Cymbopogon schoenanthus L. Spreng (lemon grass) from Tunisia. Food Sci and Technol. 2010;43(2):331-336. doi: 10.1016/j.Iwt.2009.08.004

13. Harbone JB. Phytochemical methods. 49-188. A guide to modern techniques of plant analysis. London: Chapman and Hall Ltd. 1973.

14. Slinkard K, Singleton VL. Total phenol analysis; automation and comparison with manual methods. Am J Enol Viticult. 1977;28:49-55.

15. Ardestin A, Yazdanparast R. Inhibitory effects of Ethyl acetate extract of Teucrium polium on in vitro protein glycoxidation. Food Chem Toxicol. 2007;45(12):24022411. doi: 10.1016/j.fct.2007.06.020

16. Jaberian H, PiriK, NazariJ. Phytochemical compositionand in vitro antimicrobial and antioxidant activities of some medicinal plants. Food Chem. 2013;136(1):237-244. doi: 10.1016/j.foodchem.2012.07.084

17. CLSI-Publishes. Antimicrobial susceptibility testing standards. 2009.

18. Eloff JN. A sensitive and quick microplate method to determine the Minimal Inhibitory Concentration of plant extracts for bacteria. Planta Med. 1998;64(8):711-713. doi: 10.1055/s-2006-957563

19. Razafintsalama VE, Rasoarivelo STR, et al. Antibacterial activities of fourteen medicinal plants from the endemic plant diversity of Madagascar. S Afr J Bot. 2017;112:303-306. doi: 10.1016/j.sajb.2017.06.006

20. CLSI-Publishes. Clinical and Laboratory Standards Institute Performance Standards for Antimicrobial Susceptibility Testing, Fifteenth Informational Supplement, Approved Standard MS100S15. Wayne, 


\section{P.A. 2005.}

21. Sandasi $\mathrm{M}$, Leonard $\mathrm{CM}$, Viljoen $\mathrm{AM}$. The in vitro anti biofilm activity of selected culinary herbs and medicinal plants against Listeria monocytogenes. Lett Appl Microbiol. 2010;50(1):30-35. doi: 10.1111/j.1472765X.2009.02747.x

22. Manju S, Malaikozhundan B, Vijayakumar S, et al. Antibacterial, antibiofilm and cytotoxic effects of Nigella sativa essential oil coated gold nanoparticles. Microbiol pathog. 2016;91:129-135. doi: 10.1016/j. micpath.2015.11.021

23. Khaled-Khodja N, Boulekbache-Makhlouf L, Madani $K$. Phytochemical screening of antioxidant and antibacterial activities of methanolic extracts of some Lamiaceae. Indust Cro Prod. 2014;61:41-48. doi: 10.1016/j.indcrop.2014.06.037

24. Chew Y-L, Goh J-K, Lim Y-Y. Assessment of in vitro antioxidant capacity and polyphenolic composition of selected medicinal herbs from Leguminosae family in peninsular Malaysia. Food Chem. 2009;116(1):13-18. doi: 10.1016/j.foodchem.2009.01.091

25. Bamoniri A, Ebrahimabadi AH, Mazoochi A, Behpour M, Kashi FJ, Batooli H. Antioxidant and antimicrobial activity evaluation and essential oil analysis of Semenovia tragioides Boiss. from Iran. Food Chem. 2010;122(3):553-558. doi: 10.1016/j. foodchem.2010.03.009

26. Muruzovic MZ, Mladenovic KG, Stefanovic OD, Vasic SM, Comic LR. Extract of Agrimonia euparorial L. as source of biologically active compounds and evaluation of their antioxidant, antimicrobial and antibiofilm activities. J Food Drug Anal. 2016;24(3):539-547. doi: 10.1016/j.jfda.2016.02.007

27. Khadri A, Serralheiro MLM, Nogueira JMF, Neffati M, Smiti S, Araujo MEM. Antioxidant and antiacetylcholinesterase activities of essential oils from Cymbopogon schoenanthus L. Spreng. Determination of chemical composition by GC-mass spectrometry and ${ }^{13} \mathrm{C}$ NMR. Food Chem. 2008;109(3):630-637.doi: 10.1016/j.foodchem.2007.12.070

28. Al-Fatimi M, Wurster M, Schroder G, Lindequist U. Antioxidant, antimicrobial and cytotoxic activities of selected medicinal plants from Yemen. J Ethnopharmacol. 2007;111(3):657-666. doi: 10.1016/j. jep.2007.01.018

29. Ksouri R, Megdiche W, Falleh H, et al. Influence of biological, environnemental and technical factors on phenolic content and antioxidant activities of Tunisian halophytes. CR Biol. 2008;331(11):865-873. doi: 10.1016/j.crvi.2008.07.024

30. Rempe CS, Burris KP, Lenaghan SC, Stewart CN Jr. The Potential of Systems Biology to Discover Antibacterial Mechanisms of Plant Phenolics. Front Microbiol. 2017;8:422. doi: 10.3389/fmicb.2017.00422

31. Sonesson A, Przybyszewska K, Eriksson S, et al. Identification of bacterial biofilm and the Staphylococcus aureus derived protease, staphopain, on the skin surface of patients with atopic dermatitis. Sci Rep. 2017;18:8689. doi: 10.1038/s41598-01708046-2

32. Silva-Santana G, Lenzi-Almeida KC, Lopes VGS, Aguiar-Alves F. Biofilm formation in catheter-related infections by Panton-Valentine leukocidin-producing Staphylococcus aureus. Int Microbiol. 2016;19:199207.

33. Alam J, Subhan F, Ullah I, Shahid M, Ali G, Sewell RDE. Synthetic and natural antioxidants attenuate cisplatininduced vomiting. BMC Pharmacol Toxicol. 2017;18:4. doi: 10.1186/s40360-016-0110-9

34. Yagi S, Mohammed ABA, Tzanova T, et al. Chemical profile, antiproliferative, antioxidant, and enzyme inhibition activities and docking studies of Cymbopogon schoenanthus (L.) Spreng. and Cymbopogon nervatus (Hochst.) Chiov. from Sudan. J Food Chem. 2020;44(2):e13107. doi: 10.1111/ jfbc. 13107 